Research Paper

\title{
Detection of Lyme Disease Bacterium, Borrelia burgdorferi sensu lato, in Blacklegged Ticks Collected in the Grand River Valley, Ontario, Canada
}

\author{
John D. Scott ${ }^{1}$, Janet E. Foley², John F. Anderson³ ${ }^{\circledR}$ Kerry L. Clark ${ }^{4}$, Lance A. Durden ${ }^{5}$ \\ 1. Research Division, Lyme Ontario, Fergus, Ontario Canada N1M 2L7; \\ 2. Department of Medicine and Epidemiology, School of Veterinary Medicine, University of California, Davis, USA 95616; \\ 3. Department of Entomology and Center for Vector Ecology and Zoonotic Diseases. The Connecticut Agricultural Experiment Station, New Haven, \\ Connecticut, USA 06504; \\ 4. Epidemiology \& Environmental Health, Department of Public Health, University of North Florida, Jacksonville, USA 32224; \\ 5. Department of Biology, Georgia Southern University, Statesboro, Georgia 30458, USA. \\ $\triangle$ Corresponding author: John D. Scott, Research Division, Lyme Ontario, 365 St. David Street South, Fergus, Ontario, Canada N1M 2L7. E-mail: \\ jkscott@bserv.com. \\ (C) Ivyspring International Publisher. This is an open access article distributed under the terms of the Creative Commons Attribution (CC BY-NC) license \\ (https://creativecommons.org/licenses/by-nc/4.0/). See http://ivyspring.com/terms for full terms and conditions.
}

Received: 2016.09.29; Accepted: 2016.12.28; Published: 2017.02.08

\begin{abstract}
We document the presence of blacklegged ticks, Ixodes scapularis, in the Grand River valley, Centre Wellington, Ontario. Overall, 15 (36\%) of 42 I. scapularis adults collected from 41 mammalian hosts (dogs, cats, humans) were positive for the Lyme disease bacterium, Borrelia burgdorferi sensu lato (s.l.). Using real-time PCR testing and DNA sequencing of the flagellin (fla) gene, we determined that Borrelia amplicons extracted from I. scapularis adults belonged to B. burgdorferi sensu stricto (s.s.), which is pathogenic to humans and certain domestic animals. Based on the distribution of $I$. scapularis adults within the river basin, it appears likely that migratory birds provide an annual influx of $I$. scapularis immatures during northward spring migration. Health-care providers need to be aware that local residents can present with Lyme disease symptoms anytime during the year.
\end{abstract}

Key words: Blacklegged tick, Ixodes scapularis, Lyme disease, Borrelia burgdorferi, Infection prevalence, Grand River valley.

\section{Introduction}

The blacklegged tick, Ixodes scapularis Say (northern populations previously considered as $I$. dammini) (Acari: Ixodidae), is a blood-sucking ectoparasite that is indigenous to North America east of the Rocky Mountains. This tick species has been collected from songbirds (Passeriformes) from as far north and as far west as the municipality of Slave Lake, Alberta, Canada [1,2]. In nature, I. scapularis is a vector of a diverse array of protozoan, viral, and bacterial pathogens that can cause virulent diseases in animals, including humans [3].

The Lyme disease spirochete, Borrelia burgdorferi sensu lato (s.l.), is typically carried and transmitted by several hard-bodied ticks (Acari: Ixodidae) [4]. Globally, the B. burgdorferi s.l. complex consists of at least 23 genospecies and genomospecies. In North
America, at least 9 B. burgdorferi s.l. genospecies are characterized, namely $B$. americana, B. andersonii, $B$. bissettii, B. burgdorferi sensu stricto (s.s.), $B$. californiensis, B. carolinensis, B. garinii, B. kurtenbachii, and $B$. mayonii [5-13]. Of these genospecies, $B$. americana, B. andersonii, B. bissettii, B. burgdorferi s.s., B. garinii, B. kurtenbachii, and B. mayonii are pathogenic to humans [14-17]. World-wide, Lyme disease has been diagnosed in over 80 countries [18].

In March 1995, an engorged I. scapularis female was collected from an untravelled canine living at Elora, Ontario; this represents the first record of this tick species in Centre Wellington (JDS). In the same locality, a B. burgdorferi s.l.-infected I. scapularis female was collected from a feral feline in 1999; this is the first record of a blacklegged tick positive for the Lyme 
disease bacterium in this vicinity [19]. Human Lyme disease cases have been reported in Centre Wellington dating back to 1989. During a 16-year period (2001-2016), an accumulated total of 27 people have contracted Lyme disease in Centre Wellington.

Biogeographically, B. burgdorferi-positive $I$. scapularis larvae and nymphs have been collected from migratory songbirds during northward spring migration at Ruthven Park, which is situated on the Grand River south of Centre Wellington [20-22]. These larval and nymphal I. scapularis likely originate from the southern fringe of Canada or from the central and eastern United States where $27-47 \%$ of the I. scapularis adults are positive for B. burgdorferi s.1. [23, 24]. Of note, Scott et al. [1] reported an Ixodes baergi tick on a American Cliff Swallow, Petrochelidon pyrrhonota, collected at Elora, Ontario.

During northward spring migration, passerine migrants import I. scapularis larvae and nymphs into Canada from as far south as Florida and northeastern Mexico [25]. In addition, Neotropical and southern temperate passerine migrants can transport several species of Ixodes species (i.e., I. affinis, I. brunneus, I. dentatus, I. minor) and Amblyomma species (i.e., A. americanum, A. dissimile, A. longirostre, A. maculatum, $A$. rotundatum) from southern latitudes, and disperse them across Canada [1, 2, 18-22, 26]. All of these tick species can harbour tick-associated pathogens that cause diseases in humans and domestic animals [3, 27]. In particular, blacklegged ticks can harbour and transmit a wide array of tick-associated pathogens. These zoonotic pathogens include: Babesia spp. (e.g., B. duncani, B. microti), Bartonella spp. (e.g., B. henselae), Ehrlichia spp. (e.g., E. ewingii), Mycoplasma spp. (e.g., $M$. fermentans) [28], Anaplasma spp. (e.g., A. phagocytophilum), Borrelia miyamotoi (relapsing fever group spirochete), Ehrlichia muris-like agent, and Deer Tick Virus (Powassan virus group) [29]. Of epidemiological importance, $I$. scapularis can pass the human pathogen, $B$. miyamotoi via transovarial transmission to eggs and, subsequently, to larvae [30, 31].

When ground-foraging songbirds make landfall at an established population of $I$. scapularis, they can become parasitized by I. scapularis larvae and nymphs. Since there can be upwards of 1,000 I. scapularis larvae questing at an oviposition site, a ground-frequenting songbird can become heavily infested with larvae. Because $I$. scapularis immatures acquire blood meals at different rates, fully engorged ticks can drop off at various stopover locations along the migratory flight path. Stopovers are often located in forested areas, such as ecotones (woods' edge). These wooded corridors commonly follow rivers. Heavily infested songbirds can drop numerous I. scapularis larvae and nymphs in tick-conducive habitats, and start new Lyme disease foci $[32,33]$.

The purpose of this study was to determine the infection prevalence of B. burgdorferi s.l. in I. scapularis ticks collected from cats, Felis catus; dogs; Canis lupus familiaris; and humans, Homo sapiens, residing within the Grand River valley, which runs through Centre Wellington, and to ascertain if these ticks are a public health risk.

\section{Materials and Methods}

A 3.5-year, tick-host study (2013-2016) was conducted in the Grand River valley between Inverhaugh, Ontario ( $\left.43^{\circ} 38^{\prime} 20^{\prime \prime} \mathrm{N}, 80^{\circ} 26^{\prime} 21^{\prime \prime} \mathrm{W}\right)$ and Belwood, Ontario ( $\left.43^{\circ} 47^{\prime} 31^{\prime \prime} \mathrm{N}, 80^{\circ} 19^{\prime} 22^{\prime \prime} \mathrm{W}\right)$. The river basin transects Centre Wellington, and encompasses urban municipalities and agricultural farmland (Figure 1). The predominant coniferous species are Eastern white cedar, Thuja occidentalis, and Norway spruce, Picea abies. The most prevalent deciduous tree species, which are native to the area, consist of: sugar maple, Acer saccharum; Manitoba

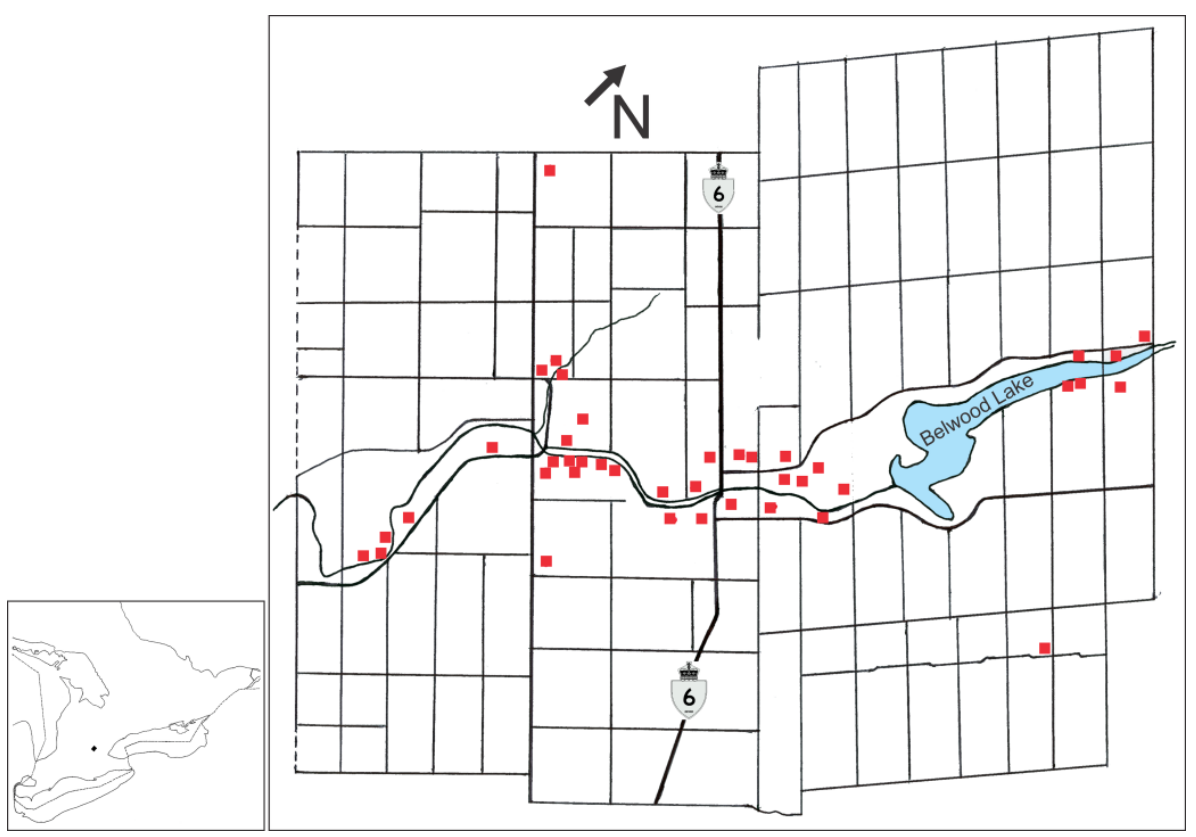

Figure 1. Map of Centre Wellington study area where Ixodes scapularis ticks were collected. 
maple, Acer negundo; black walnut, Juglans nigra; silver maple, Acer saccharinum; and bur oak, Quercus macrocarpa.

The Grand River valley supports a wide range of wildlife mammals that are found commonly in deciduous forests in northeastern North America. The most prevalent large mammal is the white-tailed deer, Odocoileus virginianus. Although they are not competent reservoirs of $B$. burgdorferi s.l., they support I. scapularis reproduction [34]. Mid-sized mammals include eastern gray squirrel, Sciurus carolinesis; red squirrel, Tamiasciurus hudsonicus; eastern cottontail rabbit, Sylvilagus floridanus; raccoon, Procyon lotor; and striped skunk, Mephitis mephitis. Small mammals include deer mice, Peromyscus maniculatus; meadow vole, Microtus pennsylvanicus; northern short-tailed shrew, Blarina brevicauda; eastern chipmunk, Tamias striatus; and house mouse, Mus musculus.

\section{Tick collection}

Veterinarians and local residents provided ticks that were obtained from mammalian hosts that included cats, dogs, and people. As a tick guide, we prepared and distributed a colored chart showing four species of ticks, which have been identified in the area. These tick species include the blacklegged tick, groundhog tick (Ixodes cookei), American dog tick (Dermacentor variabilis), and lone star tick (Amblyomma americanum). Each veterinarian was given a pad of 'Tick-Host Information' sheets, and asked to complete and submit one with each tick specimen. The background information included: host, location/residency of companion animal, travel history, date collected, and collector. Animals with a history of travel were excluded from the study. Veterinarians removed ticks with fine-point, stainless steel tweezers, and placed them in round-bottom, 8.5 $\mathrm{mL}$ polypropylene tubes $(15.7 \times 75 \mathrm{~mm})$ labelled with background information. A 7-mm hole was drilled in the polyethylene push caps (15.7 $\mathrm{mm}$ diameter) for ventilation. To prevent ticks from escaping, tulle netting was placed over the mouth of the vial before the push cap was inserted. The capped vials were then placed in self-sealing, double-zipper, plastic bags with a section of slightly moistened paper towel. Ticks were directly delivered to the tick identification laboratory (JDS) for examination and recording. Ticks were identified morphologically using taxonomic keys [35-37].

Flagging was done at one location where individual I. scapularis females were collected from the same dog for 2 consecutive years.

In order to check the winter hardiness of $I$. scapularis, we placed 10-20 adults in a deciduous woodlot each fall $(2013,2014,2015)$, and collected them the following spring. They were placed in vented polyethylene vials, which were inserted into a vented, plastic canister $(63 \mathrm{~mm} \times 135 \mathrm{~mm})$. This container was covered with aluminum hardware screen for mouse exclusion. The screened canister was then put in an open-ended wooden crate $(80 \mathrm{~mm} \times 125$ $\mathrm{mm} \times 150 \mathrm{~mm}$ ) for cervid hoof protection. A layer of deciduous leaves was placed over the overwinter box to reflect the surrounding leaf layer.

We examined bird-tick data obtained during a 6-year period (2011-2016) in southwestern Ontario; ticks were collected from songbirds in the lower Grand River valley, which is directly south of our study area.

\section{Spirochete detection}

In order to undertake B. burgdorferi s.l. testing, we had 3 separate delivery phases: phase 1 (3 May 2013 to 31 May 2014), phase 2 (26 October 2014 to 7 May 2015), and phase 3 (7 June 2015 to 7 June 2016). In phase 1 , ticks were sent by courier to a laboratory (JFA) for culturing and PCR amplification. Live ticks were cultured, and these ticks and dead ticks were later tested for B. burgdorferi s.l. using DNA extraction and PCR amplification of the highly-conserved, outer surface protein A $(O s p A)$ gene. The DNA detection methods have been previously described [38-40]. During phase 2, ticks were put in $2 \mathrm{~mL}$ micro tubes containing $94 \%$ ethyl alcohol, and sent by courier to a separate laboratory (KLC) for B. burgdorferi s.l. testing and molecular analysis. DNA extraction and PCR testing using the flagellin $\mathrm{B}$ (flaB) gene were performed as previously described [41]. For phase 3, each tick was put in a $2 \mathrm{~mL}$ micro tube containing $94 \%$ ethyl alcohol, and sent by courier to the PCR amplification laboratory (JEF). The laboratory procedures, including DNA extraction, PCR testing, DNA sequencing, and amplicon evaluation were conducted as previously described [42]. The flagellin (fla) gene was amplified.

\section{Nucleotide sequences}

DNA sequences of the fla gene of B. burgdorferi s.s. amplicons were deposited in the GenBank database with accession numbers: KX085197 for tick 15-5A84A, KX085198 for tick 15-5A84B, KX085199 for 15-5A100, and KX085200 for tick 15-5A106.

\section{Results}

\section{Tick collection}

During the 3.5-year study (May 2013 to August 2016), 42 I. scapularis ticks were collected from 41 mammalian hosts (4 cats, 29 dogs, 8 humans) in the Grand River valley (Table 1) (Figure 1, 2). We collected four other species of ticks in the Grand River 
corridor, namely A. americanum, A. maculatum (Gulf Coast tick), D. variabilis, and I. cookei. Of special note, a fully engorged $A$. americanum female was collected on 19 August 2013 from a dog with no history of travel. Likewise, a slightly engorged $A$. maculatum female was collected from a dog with no history of travel on 27 August 2016. These Amblyomma ticks were likely imported by migratory songbirds as nymphs during northward spring migration and, subsequently, molted to females during the summer.

When we conducted flagging where individual $I$. scapularis females had been collected from the same dog for 2 consecutive years, we were unable to find any more I. scapularis adults.

When the I. scapularis adults, which were placed in local wooded area to overwinter, where checked in the spring, the overwinter survival rate was $95 \%$ (range, 90-100\%).

Table 1. Presence of Borrelia burgdorferi s.l. in Ixodes scapularis adults collected from mammalian hosts residing in the Grand River valley, 2013-2016

\begin{tabular}{|l|l|l|l|}
\hline Host & $\begin{array}{l}\text { No. of } \\
\text { hosts }\end{array}$ & $\begin{array}{l}\text { No. of ticks } \\
\text { collected }\end{array}$ & $\begin{array}{l}\text { No. of ticks } \\
\text { PCR pos. (\%) }\end{array}$ \\
\hline Cat, Felis catus & 4 & 4 & $1(25)$ \\
\hline $\begin{array}{l}\text { Dog, Canis lupus } \\
\text { familiaris }\end{array}$ & 29 & 30 & $10(33)$ \\
\hline Human, Homo sapiens & 8 & 8 & $4(50)$ \\
\hline Total & 41 & 42 & $15(36)$ \\
\hline
\end{tabular}

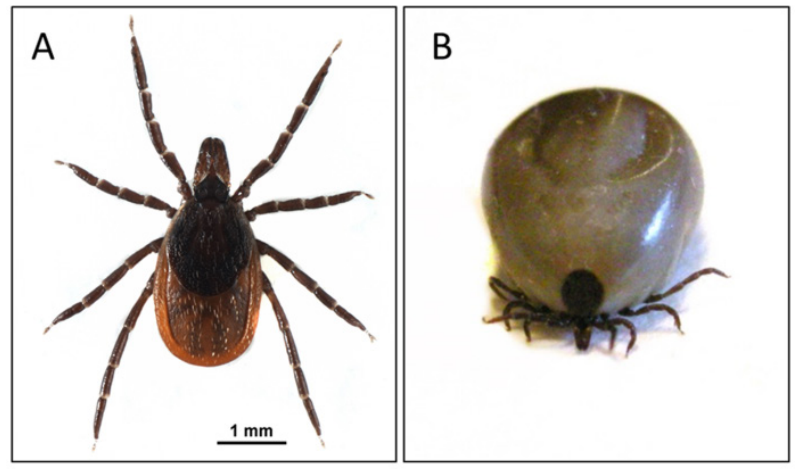

Figure 2. Ixodes scapularis: A. unfed female; and B. fully engorged female, body length: $9.3 \mathrm{~mm}$. Photo credits: Elizabeth J. Sears.

\section{Spirochete detection}

In total, $15(36 \%)$ of 42 I. scapularis adults, were infected with B. burgdorferi s.l. (Table 1). Based on DNA sequencing of the flagellin $(f l a)$ gene of Borrelia amplicons from four ticks (15-5A84A, 15-5A84B, 15-5A100, 15-5A106), we determined that they belong to $B$. burgdorferi s.s., which is pathogenic to people and certain domestic animals. Interestingly, one dog was co-infested with two I. scapularis females, and the DNA sequences of the B. burgdorferi s.l. amplicons were slightly different. This molecular phenomenon suggests that these two co-feeding ticks had fed on two different vertebrate sources, as larvae or nymphs, before the resulting I. scapularis females parasitized the host dog. Amplicons of B. burgdorferi s.l. from four I. scapularis adults were DNA sequenced, and characterized as B. burgdorferi s.s. Of 5 I. cookei (2 females, 3 nymphs) tested, one nymph was positive for B. burgdorferi s.l.; it was collected from an adult human female. Even though many of the ixodid ticks were PCR-negative for Lyme disease spirochetes, they could have been infected with a wide diversity of other tick-transmitted pathogens. Certain tick species (i.e., A. americanum, A. maculatum, D. variabilis) were not tested for B. burgdorferi s.l.

In 1993, fifteen small mammals (8 deer mice, 5 northern short-tailed shrews, 1 eastern chipmunk, 1 red squirrel) were collected in the area encompassing Fergus, Ontario; 2 northern short-tailed shrews were PCR-positive for B. burgdorferi s.l. As well, spirochetes were observed in organs (ear, heart, kidney, spleen, liver, bladder) of these shrews using anti-B. burgdorferi s.l. antibody fluorescent stain and dark-field microscopy (S. N. Banerjee, unpublished data).

During a 6-year period (2011-2016), we collected 34 I. scapularis immatures (32 nymphs, 2 larvae) from songbirds in the lower Grand River riverine corridor. Of these ticks, 11 (34\%) of 32 I. scapularis nymphs were infected with B. burgdorferi s.l.

\section{Discussion}

We document a $36 \%$ infection prevalence of $B$. burgdorferi s.l. in I. scapularis adults collected from dogs, cats, and people in the upper Grand River valley. Additionally, we provide circumstantial evidence that migratory songbirds introduce $I$. scapularis nymphs during spring migration, and drop them randomly along the Grand River riverine corridor. Most importantly, these B. burgdorferi s.l.-infected I. scapularis pose a public health risk to people and domestic animals.

\section{Epidemiology of Lyme disease in Grand River valley}

Lyme disease has been present in the Grand River valley for decades. The first reported case of Lyme disease in Centre Wellington was in 1989; an infected human adult male with no history of travel was recognized. In 1993, a small mammal study was conducted in the Fergus area, and northern short-tailed shrews were PCR-positive for $B$. burgdorferi s.l. In addition, Lyme disease spirochetes 
were observed in tissues of these shrews using dark-field microscopy and anti-B. burgdorferi s.l. antibody fluorescent stain. During a 10-yr, tick-host study [19], an engorged I. scapularis female was collected from an untraveled dog at Elora, Ontario on 10 March 1995; this tick constitutes the first I. scapularis tick reported in Centre Wellington. A fully engorged I. scapularis female was collected from an untravelled cat, which was living near Alma on 18 December 1999. Not only was the attached I. scapularis tick positive for B. burgdorferi s.l., the host cat was serologically positive and symptomatic for Lyme disease. Of epidemiological significance, 4 (50\%) of 8 I. scapularis adults on humans were infected with $B$. burgdorferi s.l. These tick-host-pathogen findings clearly show that I. scapularis ticks have been present in the Grand River corridor for decades, and have caused Lyme disease in local residents.

\section{Prevalence of B. burgdorferi s.I. in I. scapularis}

Our findings reveal a $36 \%$ infection prevalence for B. burgdorferi s.l. in I. scapularis adults collected in the Grand River valley. This infection prevalence is within the range reported in other studies in the upper Midwest and the northeastern United States, which range from $27-47 \%$ [20, 21]. Similarly, Scott et al. [43] reported a B. burgdorferi s.l. infection prevalence of $41 \%$ in I. scapularis adults collected recently in the Hamilton-Wentworth, Ontario region. Unlike B. miyamotoi, transovarial transmission of $B$. burgdorferi s.l. from I. scapularis females to larvae does not occur [31]. Therefore, any I. scapularis larvae, which are infected with B. burgdorferi s.l., must have acquired infection from spirochetemic mammals in Centre Wellington or from reservoir-competent, migratory songbirds.

\section{Absence of $I$. scapularis nymphs}

During the study period, I. scapularis nymphs were not submitted or collected. These findings are consistent with a 10-yr, tick-host study (1993-2002) conducted with veterinary clinics across Ontario [19]. On the other hand, I. cookei nymphs were collected from domestic animals and people. This phenomenon suggests that $I$. cookei is established locally, whereas $I$. scapularis is not. The absence of I. scapularis nymphs on domestic animals and people in this locality suggests that this tick is introduced annually by passerine migrants. Bird parasitism by I. scapularis immatures is present in the Grand River riverine corridor [22-24]. A bird bander, who is located at a more southerly location along the Grand River, has collected I. scapularis immatures during northward spring migration. When these I. scapularis nymphs are released at more northerly locations in Canada, the $B$. burgdorferi s.l. infection prevalence stays the same in adults. Notably, this infection prevalence $(34 \%)$ has been reflected in Centre Wellington in I. scapularis adults.

\section{Tick dispersal by birds}

Songbirds play a significant role in the wide dispersal of bird-feeding ticks during northward spring migration. As passerine migrants fly north to seasonal breeding grounds, they are parasitized by Lyme disease vector ticks when they make landfall and, a few days later, these replete ticks drop to the ground at more northerly stopover sites. Notably, bird-fed I. scapularis nymphs molt in 5-9 wk, and typically develop to adults from late June to early August. When recently moulted I. scapularis adults become sclerotized and their reproductive organs are fully developed, they typically start questing in Ontario for hosts in October. If they fail to parasitize a host, they overwinter during frigid temperatures under an insulating blanket of snow [44], and start host-seeking in the spring once the snow has disappeared. Since I. scapularis ticks have antifreeze-like compounds (glycoproteins) in their bodies [45], they are able to withstand subzero temperatures. In the present study, the overwinter survival of I. scapularis adults was $95 \%$. Therefore, people must be vigilant that $I$. scapularis ticks are actively engaged in host-seeking activities in Ontario when the snow disappears in the spring until sustained snowfall in the late fall.

The prevalence of B. burgdorferi s.l. (36\%) in I. scapularis adults from mammalian hosts in our study is consistent with the prevalence of Lyme disease spirochetes in I. scapularis nymphs $(35 \%)$ collected from songbirds in central and eastern Canada [22]. This phenomenon provides circumstantial evidence that migratory songbirds are the source of I. scapularis ticks in the Grand River riverine corridor. Furthermore, Morshed et al. [19] found that all of the I. scapularis ticks collected from animals during a 10-year, tick-host study conducted across Ontario were adults, which implies wide dispersal of ticks by songbirds.

In the present study, an $A$. americanum female was collected from an untravelled dog in mid-summer. Since A. americanum ticks are not indigenous to Canada, it is most likely that a southern temperate or Neotropical songbird transported this $A$. americanum specimen, as a nymph, to the Grand River area during northward spring migration [1]. Subsequently, after the nymph dropped into the cool, moist leaf litter, and molted to a female in 6-10 wk, it parasitized the dog in August. In addition, the collection of a Gulf Coast tick on an untravelled dog in 
late August reveals that passerine migrants are also implicated in the importation of this tick into Canada. Since A. maculatum is not indigenous to Canada, this tick, in all likelihood, was transported to the area by a southern temperate or Neotropical songbird during spring migration and, during the summer, molted to a female. Biogeographically, A. maculatum immatures have been collected in Canada from migratory songbirds during northward spring migration $[1,18$, $26,35]$. The collection of an A. maculatum female in the Grand River area provides further evidence that migratory songbirds are transporting bird-feeding ticks into southern Canada. Notably, Amblyomma species can harbour a wide array of tick-borne pathogens that can be transmitted to domestic animals and people [3].

Migratory songbirds can transport bird-derived ticks hundreds of kilometres into Canada during annual spring migration from as far south as the southern United States, the Caribbean, and Central and South America [1, 2, 18-22, 26, 46-48]. Not only do long-distance migrants provide an influx of $I$. scapularis immatures, they contribute to the establishment of Lyme disease foci [33, 49]. Since passerine migrants widely disperse Lyme disease vector ticks, people do not have to visit an endemic area to contract Lyme disease.

\section{Diversity of B. burgdorferi s.I.}

In the present study, two I. scapularis females were collected from a single, untraveled dog on the same day. Surprisingly, these females harbored slightly different strains of B. burgdorferi s.l. The genetic difference of $B$. burgdorferi s.l. in these two ticks, was a single nucleotide substitution. Even though these two ticks were co-feeding on the same $\mathrm{dog}$, the genetic variation suggests that these ticks originated from different geographic sources. It is noteworthy that one I. scapularis immature could have parasitized a songbird at one stopover, whereas another passerine migrant was parasitized at another stopover. Alternatively, a songbird could have become co-infected with two different strains of $B$. burgdorferi s.l., and transmitted them to co-feeding nymphal I. scapularis [50]. Since passerine migrants make landfall at different Lyme disease foci along the migratory flight path, they can introduce a wide diversity of ticks and Lyme disease spirochetes into the Grand River corridor. Richter et al. [51] reveal that the American Robin, Turdus migratorius, is a reservoir-competent host of $B$. burgdorferi s.l. Furthermore, B. burgdorferi s.l. has been isolated from the blood and skin of passerines [52-55]. Moreover, $B$. burgdorferi s.l. has been detected in songbird-derived $I$. scapularis larvae, which indicates that many passerines are reservoirs of Lyme disease spirochetes $[21,22,53,56]$. Migratory songbirds are known to transport I. scapularis immatures with more than one tick-borne pathogen. For example, a nymphal $I$. scapularis was collected from a Veery, Catharus fuscescens, co-infected with B. burgdorferi s.l., Babesia microti (human babesiosis), and Anaplasma phagocytophilum (human anaplasmosis) [57]. In Michigan, Hamer et al. [58] reported Borrelia andersonii and, likewise, B. miyamotoi in $I$. dentatus, and $I$. scapularis collected from passerine birds. Additionally, $B$. andersonii has been detected in patients in the southeastern United States [15]. Not only do songbirds act as reservoirs of B. burgdorferi s.l., they are disseminators of borreliae and other tick-borne pathogens.

\section{Clinical and Zoonotic Implications}

Our study reveals that I. scapularis ticks collected in the Grand River valley harbour B. burgdorferi s.s., which is pathogenic to humans. This microorganism causes Lyme disease, a multisystem spirochetosis. As this zoonotic disease progresses, patients commonly experience fatigue, joint pain, neurologic symptoms, and cognitive dysfunction. When a $B$. burgdorferi s.l.-infected I. scapularis tick takes a blood meal, it can transmit spirochetes and, if co-infected, it can transmit one or more of at least 8 tick-transmitted, pathogenic microorganisms. During I. scapularis attachment, $B$. burgdorferi s.l. can be transmitted in less than 24 hours, especially if the tick salivary glands are infected [59]. During the initial phase of cutaneous infection following a tick bite, patients may have an erythema migrans rash that may be bull's-eye shaped or atypical; however, less than $42 \%$ of patients have these rashes $[60,61]$. Therefore, when someone is bitten by an I. scapularis tick, that individual should seek medical attention and prophylactic antimicrobial treatment.

In humans, B. burgdorferi s.l. has diverse forms (i.e., spirochetes, blebs, granules, round bodies, atypical forms). Spirochetes shape-shift into round bodies and hide in gelatinous shields called biofilms allowing this highly adaptable microbe to become a stealth pathogen. In addition, spirochetes will attach to, invade, and kill human B and T lymphocytes [62]. As spirochetes spread in the body, a multitude of clinical manifestations can unfold, including fatigue, headaches, low-grade fever, stiff neck/back, disturbed sleep, memory loss and cognitive dysfunction. Migratory joint aches and nerve inflammation with numbness and tingling are typical symptoms. This illness can affect several body systems: cardiac, endocrine, gastrointestinal, musculoskeletal, neurological, ontological, and 
ophthalmological [63]. Neurological deficits are common in both children and adults. As spirochetes attack nerves and ligamentous tissue, they produce neurotoxins that cause an inflammatory response in the surrounding tissue [64,65]. As the spirochetemia progresses in the central nervous system, demyelination may occur with cytokine dysregulation and profound fatigue $[65,66]$.

Left untreated or inadequately treated, $B$. burgdorferi s.l. will hide in deep tissues, such as bone [67], brain [68-70], eye [71], muscle [72], collagenous tissues (ligaments, tendons) [73, 74], glial and neuronal cells [75, 76], and fibroblast/scar tissue [77]. Lack of response to treatment can be due to persistent infection caused by spirochete sequestration in tissues or biofilm formation. In some cases, this persistent infection is fatal $[68,78]$. Since $B$. burgdorferi can be persistent, Lyme disease spirochetes have been detected in and cultured from tissues and body fluids after conventional, short-term antibiotic treatment in animals and humans [79-84]. Since spirochetes lodge in human testicles, semen, and vaginal secretions, $B$. burgdorferi s.l. may be sexually transmitted $[85,86]$. Lyme disease can destroy people's lives, and $B$. burgdorferi s.l. infection should be considered among the differential diagnoses for patients who have signs and symptoms suggestive of tick-borne illness.

In conclusion, our findings underpin the fact that multiple species of ticks are present in the Grand River valley, and $36 \%$ of the I. scapularis adults are infected with B. burgdorferi s.l. The close similarity of the $B$. burgdorferi s.l. infection prevalence of $I$. scapularis adults on mammalians hosts, including people, and the infection prevalence of I. scapularis nymphs in eastern and central Canada indicates that migratory songbirds are introducing $B$. burgdorferi s.l.-infected ticks into Centre Wellington annually. Health-care providers need to be aware that $I$. scapularis ticks infected with pathogenic B. burgdorferi s.s. are present in the Grand River valley, and present a public health risk.

\section{Acknowledgments}

We thank local veterinarians who collected ticks from companion animals. We are grateful to Elizabeth A. Alves, Kenny Lou, Jodi Manord and Morgan Smith for technical assistance. We are indebted to John Ward for computer graphics and to Elizabeth J. Sears for the tick photographs and associated computer graphics. This research was supported in part by Lyme Ontario.

\section{Competing Interests}

The authors confirm that they have no conflicts of interest that could bias any aspect of the present paper. They have no financial interests in, relationships with, or have received no funding from any clinical laboratories or test kit companies or reagent manufactures mentioned in the paper.

\section{References}

1. Scott JD, Fernando K, Banerjee SN, et al. Birds disperse ixodid (Acari: Ixodidae) and Borrelia burgdorferi-infected ticks in Canada. J Med Entomol. 2001; 38: 493-500. doi:10.1603/0022-2585-38.4.493

2. Morshed MG, Scott JD, Fernando K, et al. Migratory songbirds disperse ticks across Canada, and first isolation of the Lyme disease spirochete, Borrelia burgdorferi, from the avian tick, Ixodes auritulus. J Parasitol. 2005; 91: 780-790. doi:10.1645/GE-3437.1

3. Nicholson WL, Sonenshine DE, Lane RS \& Uilenberg G. Ticks (Ixodoidea). In: Mullen GR \& Durden LA, eds. Medical and Veterinary Entomology, 2nd edition. Amsterdam: Elsevier, Inc. 2009: 493-542.

4. Burgdorfer W, Barbour AG, Hayes SF, et al. Lyme disease-a tick-borne spirochetosis? Science. 1982; 216: 1317-1319. doi:10.1126/science.7043737

5. Baranton G, Postic D, Saint Girons I, et al. Delineation of Borrelia burgdorferi sensu stricto, Borrelia garinii sp. nov. and group VS461 associated with Lyme borreliosis. Int J Syst Bacteriol. 1992; 42: 378-383. doi: 10.1099/00207713-42-3-378

6. Marconi RT, Liveris D, Schwartz I. Identification of novel insertion elements, restriction fragment length polymorphism patterns, and discontinuous $23 \mathrm{~S}$ rRNA in Lyme disease spirochetes: phylogenetic analysis of rRNA genes and their intergenic spacers in Borrelia japonica sp. nov. and genomic group (Borrelia andersonii sp. nov.) isolates. J Clin Microbiol. 1995; 33: 2427-2434. http://www.researchgate.net/ publication/15705144_4

7. Postic D, Ras NM, Lane RS, et al. Expanded diversity among Californian Borrelia isolates and description of Borrelia bissettii sp. nov. (formerly Borrelia group DN127). J Clin Microbiol. 1998: 36: 3497-3504. http://www.ncbi.nlm.nih.gov/pmc/articles/PMC105228/

8. Smith RP, Muzaffar SB, Lavers J, et al. Borrelia garinii in seabird ticks (Ixodes uriae), Atlantic coast, North America. Emerg Infect Dis. 2006: 12: 1909-1912. doi:10.3201/eid1212.060448

9. Rudenko N, Golovchenko M, Grubhoffer L, et al. Borrelia carolinensis sp. nov., a new $\left(14^{\text {th }}\right)$ member of the Borrelia burgdorferi sensu lato complex from southeastern region of the United States. J Clin Microbiol. 2009; 47: 134-141. doi: 10.1099/ijs.0.021436-0

10. Rudenko N, Golovchenko M, Lin T, Gao L, et al. Delineation of a new species of the Borrelia burgdorferi sensu lato complex, Borrelia americana sp. nov. J Clin Microbiol. 2009; 47: 3875-3880. doi: 10.1128/JCM.01050-098

11. Margos G, Hojgaard A, Lane RS, et al. Multilocus sequence analysis of Borrelia bissettii strains from North America reveals a new Borrelia species, Borrelia kurtenbachii. Ticks Tick-borne Dis. 2010: 1: 151-158. doi: 10.1016/j.ttbdis.2010.09.002

12. Pritt BS, Mead PS, Hoang Johnson DK, et al. Identification of a novel pathogenic Borrelia species causing Lyme borreliosis with unusually high spirochaetaemia: a descriptive study. Lancet Infect Dis. 2016: 16: 556-564. http://dx.doi.org/10.1016/S1473-3099(15)00464-8. Corrections: Lancet Infect Dis. 2016; 16. http://dx.doi.org/10.1016/ S1473-3099(16)30065-2

13. Scott JD. Borrelia mayonii: prying open Pandora's box of spirochetes. Lancet Infect Dis. 2016; 16: 637. http://dx.doi.org/10.1016/ S1473-3099(16)30053-6

14. Girard YA, Fedorova N, Lane RS. Genetic diversity of Borrelia burgdorferi and detection of $B$. bissettii-like DNA in serum of north-coastal residents. J Clin Microbiol. 2011; 49: 945-954. doi: 10.1128/JCM.01689.10

15. Clark KL, Leydet B, Hartman S. Lyme borreliosis in human patients in Florida and Georgia, USA. Int J Med Sci. 2013; 10: 915-931. doi:10.7150/ijms.6273

16. Rudenko N, Golovchenko M, Vancová M, et al. Isolation of live Borrelia burgdorferi sensus lato spirochetes from patients with undefined disorders and symptoms not typical for Lyme borreliosis. Clin Microbiol Infect. 2016; 22: 267.e9-267.e15. doi:10.1016/j.cmi.2015.11.009

17. Golovchenko M, Vancová M, Clark KL, et al. A divergent spirochete strain isolated from a resident of the southeastern United States was identified by multilocus sequence typing as Borrelia bissettii. Parasit Vectors. 2016; 9: 68. doi: 10.1186/S13071-016-1353-4

18. Scott JD. Birds widely disperse pathogen-infected ticks. In: Mahala G, ed. Seabirds and Songbirds: habitat preferences conservation and migratory behavior. Birds-evolution, behavior and ecology. New York: Nova Science Publishers, Inc.; 2015: 1-22.

19. Morshed MG, Scott JD, Fernando K, et al. Distribution and characterization of Borrelia burgdorferi isolates from Ixodes scapularis and 
presence in mammalian hosts in Ontario, Canada. J Med Entomol. 2006; 43: 762-773. http://dx.doi.org/jmedent/43.4.762

20. Scott JD, Lee MK, Fernando K, et al. Detection of Lyme disease spirochete, Borrelia burgdorferi sensu lato, including three novel genotypes in ticks (Acari: Ixodidae) collected from songbirds (Passeriformes) across Canada. J Vect Ecol. 2010; 35: 124-139. doi:10.1111/j.1948.7134.2010.00068.x

21. Scott JD, Anderson JF, Durden LA. Widespread dispersal of Borrelia burgdorferi-infected ticks collected from songbirds across Canada. J Parasitol. 2012; 98: 49-59. doi: 10.1645/GE-2874.1

22. Scott JD, Durden LA. New records of the Lyme disease bacterium in ticks collected from songbirds in central and eastern Canada. Int J Acarol. 2015; 41: 241-249. http://dx.doi.org/10.1080/ 01647954.2015 .1038301

23. Turtinen LW, Kruger AN, Hacker MM. Prevalence of Borrelia burgdorferi in adult female ticks (Ixodes scapularis), Wisconsin 2010-2013. J Vect Ecol. 2015; 40: 195-197. doi: 10.1111/jvec.12152

24. Hutchinson ML, Strohecker MD, Simmons TW, et al. Prevalence rates of Borrelia burgdorferi (Spirochaetales: Spirochaetaceae), Anaplasma phagocytophilum (Rickettsiales: Anaplasmataceae), and Babesia microti (Piroplasmida: Babesiidae) in host-seeking Ixodes scapularis (Acari: Ixodidae) from Pennsylvania. J Med Entomol. 2015; 52: 693-698. http://dx.doi.org/10.1093/jme/tjvo37

25. Durden LA, Keirans JE. Nymphs of the genus Ixodes (Acari: Ixodidae) of the United States: taxonomy, identification key, distribution, hosts, and medical/veterinary importance. Monographs, Thomas Say Publications in Entomology. 1996. Entomological Society of America, Lanham, Maryland, U.S.A.

26. Ogden NH, Lindsay RL, Hanincová K, et al. Role of migratory birds in introduction and range expansion of I. scapularis ticks and of Borrelia burgdorferi and Anaplasma phagocytophilum in Canada. Appl Environ Microbiol. 2008; 74: 1780-1790. doi:10.1128/AEM.01982-07. Erratum: Appl Environ $\quad$ Microbiol. 2008; 3919. http://dx.doi.org/10.1128/AEM.00857-08

27. Guglielmone AA, Estrada-Peña A, Keirans JE, et al. Ticks (Acari: Ixodida) of the Neotropial Zoogeographic Region. Consortium on Ticks and Tick-borne Diseases - 2. Atalanta, Houten, The Netherlands; 2003

28. Eskow E, Adelson ME, Rao R-V, Mordechai E. Evidence for disseminated Mycoplasma fermentans in New Jersey residents with antecedent tick attachment and subsequent musculoskeletal symptoms. J Clin Rheumatol. 2003; 9: 77-87. doi: 10.1097/01.RHU. 0000062510.04724 .07

29. Anderson JF, Armstrong PM. Prevalence and genetic characterization of Powassan virus infecting Ixodes scapularis in Connecticut. Am J Trop Med Hyg. 2012; 87: 754-759. doi: 10.4269/ajtmh.2012.12-0294

30. Platonov AE, Karan LS, Kolyasnikova NM, et al. Humans infected with relapsing fever spirochete Borrelia miyamotoi, Russia. Emerg Infect Dis. 2011; 17: 1816-1823. http://dx.doi.org/10.3201/eid1710.101474

31. Rollend L, Fish D, Childs JE. Transovarial transmission of Borrelia spirochetes by Ixodes scapularis: a summary of the literature and recent observations. Tick Tick Borne Dis. 2013; 4: 46-51. doi: 10.1016/j.ttbdis.2012.06.008

32. Anderson JF. Mammalian and avian reservoirs for Borrelia burgdorferi. Ann N Y Acad Sci. 1988; 539: 180-191. doi:10.1111/j.1749-6632. 1988.tb31852.x

33. Scott JD, Scott CM, Anderson JF. The establishment of a blacklegged tick population by migratory songbirds in Ontario, Canada. J Vet Sci Med. 2014; 2: 5. http://dx.doi.org/10.13188/2325-4645.1000005

34. Watson TG, Anderson RC. Ixodes scapularis Say on white-tailed deer (Odocoileus virginianus) from Long Point, Ontario. J Wildl Dis. 1976; 12: 66-71. http://dx.doi.org/10.7589/0090-3558-12.1.66

35. Keirans JE, Durden LA. Illustrated key to nymphs of the tick genus Amblyomma (Acari: Ixodidae) found in the United States. J Med Entomol. 1998; 35: 489-495. doi:10.1093/jmedent/35.4.489

36. Keirans JE, Clifford CM. The genus Ixodes in the United States: a scanning electron microscope study and key to the adults. J Med Entomol. 1978 (Suppl 2: 149. doi:10.1093/jmedent/15.suppl2.1

37. Keirans JE, Hutcheson HJ, Durden LA, et al. Ixodes (Ixodes) scapularis (Acari: Ixodidae): Redescription of all active stages, distribution, hosts, geographical variation, and medical and veterinary importance. J Med Entomol. 1996; 33: 297-318. http://www.ncbi.nlm.nih.gov/ pubmed/8667375

38. Persing DH, Telford III SR, Spielman A, et al. Detection of Borrelia burgdorferi infection in Ixodes dammini ticks with the polymerase chain reaction. J Clin Microbiol. 1990; 28: 566-572. http://www.ncbi.nlm.nih.gov/pubmed/1969867

39. Persing DH, Telford SR, Rys PN, et al. Detection of Borrelia burgdorferi DNA in museum specimens of Ixodes dammini ticks. Science. 1990; 249: 1420-1423. doi:10.1126/science 2402635
40. Scott JD, Anderson JF, Durden LA. First detection of Lyme disease spirochete Borrelia burgdorferi in ticks collected from a raptor in Canada. J Vet Sci Med Diagn. 2013; 2: 4. http://dx.doi.org/10.4172/ 2325-9590.1000123

41. Scott JD, Anderson JF, Durden LA, et al. Ticks parasitizing gallinaceous birds in Canada and first record of Borrelia burgdorferi-infected Ixodes pacificus (Acari: Ixodidae) from California Quail. Syst Appl Acarol. 2016; 21: 1-12. http://doi.org/10.11158/saa.21.1.1

42. Scott JD, Foley JE. Detection of Borrelia americana in the avian coastal tick, Ixodes auritulus (Acari: Ixodidae), collected from a bird captured in Canada. Open J An Sci. 2016; 6: 207-216. http://dx.doi.org/10.4236/ ojas. 2016.63027

43. Scott JD, Anderson JF, Durden LA, et al. Prevalence of the Lyme disease spirochete, Borrelia burgdorferi, in blacklegged ticks, Ixodes scapularis at Hamilton-Wentworth, Ontario. Int J Med Sci. 2016; 13: 316-324. doi: 10.7150/ijms. 14552

44. Vandyk JK. Survival of Ixodes scapularis (Acari: Ixodidae) exposed to cold. J Med Entomol. 1986; 33: 6-10. http://dx.doi.org/10.1093/ jmedent/33.1.6

45. Heisig M, Abraham NM, Liu L, et al. Antivirulence properties of an antifreeze protein. Cell Reports. 2014; 9: 1-8. http://dx.doi.org/10.1016/j.celrep.2014.09.034

46. Scott JD, Durden LA. Songbird-transported tick Ixodes minor (Ixodida: Ixodidae) discovered in Canada. Can Entomol. 2015; 147: 46-50. doi:10.40339/tce.2014.34

47. Scott JD, Durden LA. First record of Amblyomma rotundatum tick (Acari: Ixodidae) parasitizing a bird collected in Canada. Syst Appl Acarol. 2015; 20: 155-161. http://dx.doi.org/10.11158/saa.20.2.1

48. Scott JD, Durden LA. Amblyomma dissimile Koch (Acari: Ixodidae) parasitizes bird captured in Canada. Syst Appl Acarol. 2015; 20: 854-860. http://dx.doi.org/10.11158/saa.20.8.2

49. Anderson JF, Magnarelli LA, Stafford III KC. Bird-feeding ticks transstadially transmit Borrelia burgdorferi that infect Syrian hamsters. J Wildl Dis. 1990; 26: 1-10. doi:10.7589/0090-3558-26.1.1

50. Hamer SA, Hickling GJ, Sidge JL, et al. Diverse Borrelia burgdorferi strains in a bird-tick crytic cycle. Appl Environ Microbiol. 2011; 77: 1999-2007. doi:10.1128/AEM.02479-10

51. Richter D, Spielman A, Komar N, et al. Competence of American robins as reservoir hosts for Lyme disease spirochetes. Emerg Inf Dis. 2000; 6: 133-138. doi: 10.3201/eid0602.000205

52. Anderson JF, Magnarelli LA. Avian and mammalian hosts for spirochete-infected ticks and insects in a Lyme disease focus in Connecticut. Yale J Biol Med. 1984; 57: 627-641. http://www.ncbi.nlm.nih.gov/pubmed/6516460

53. Anderson JF, Johnson RC, Magnarelli LA, et al. Involvement of birds in the epidemiology of the Lyme disease agent Borrelia burgdorferi. Infect Immun. 1986; 51: 394-396. http://www.ncbi.nlm.nih.gov/ pubmed/8370728

54. McLean RG, Ubico AR, Hughes CA, et al. Isolation and characterization of Borrelia burgdorferi from blood of a bird captured in the Saint Croix Valley. J Clin Microbiol. 1993; 31: 2038-2043.

55. Durden LA, Oliver JH, Jr, Kinsey AA. Ticks (Acari: Ixodidae) and spirochetes (Spirochaetaceae: Spirochaetales) recovered from birds on a Georgia Barrier island. J Med Entomol. 2001; 38: 231-236. doi: 10.1603/0022-2585-38.2.231

56. Hamer SA, Goldberg TL, Kitron UD, et al. Wild birds and urban ecology of ticks and tick-borne pathogens, Chicago, Illinois, USA, 2005-2010.

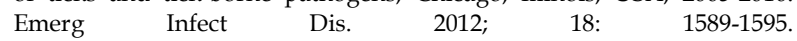
http://dx.doi.org/10.3201/eid1810.120511

57. Hersh MH, Ostfeld RS, McHenry DJ, et al. Co-infection of blacklegged ticks with Babesia microti and Borrelia burgdorferi is higher than expected and acquired from small mammal hosts. PLoS One. 2014; 9: e99348. doi:10.1371/journal.pone.0099348

58. Hamer SA, Hickling GJ, Keith R, et al. Associations of passerine birds, rabbits, and ticks with Borrelia miyamotoi and Borrelia andersonii in Michigan, U.S.A. Parasit Vectors. 2012; 5: 231 . doi: 10.1186/1756-3305-5-231

59. Cook MJ. Lyme borreliosis: a review of data on transmission time after tick attachment. Int J Gen Med. 2015; 8: 1-8. doi:10.21447/IJGM.S73791

60. Forrester JD, Meiman J, Mullins J, et al. Update on Lyme carditis, groups at high risk, and frequency of associated sudden cardiac death-United States. MMWR. 2014; 63 (43): 982-983.

61. Johnson L, Wilcox S, Mankoff J, et al. Severity of chronic Lyme compared to other chronic conditions: a quality of life survey. PeerJ. 2014: 2: e322. https://peerj.com/articles/322

62. Dorward DW, Fischer ER, Brooks DM. Invasion and cytopathic killing of human lymphocytes by spirochetes causing Lyme disease. Clin Infect Dis. 1997; 25 Suppl 1: 52-58. http://www.scottsbt.com/ maureen/momisc/lyme/pdfs/killing_lymphocytes.pdf 
63. Cameron DJ, Johnson LB, Maloney EL. Evidence assessments and guideline recommendations in Lyme disease: the clinical management of known tick bites, erythema migrans rashes and persistent disease. Expert Rev Anti-Infect Ther. 2014; 12: 1103-1135. doi:10.1586/14787210.2014.940900

64. Zijkowska JM, Hermanowska-Szpakowicz T. New aspects of the pathogenesis of Lyme disease. Przeglad Epidemiologiczny. 2002; 56 Suppl 1: 57-67. http://www.ncbi.nlm.nih.gov/pubmd/12194230

65. Horowitz RI. Why can't I get better? Solving the mystery of Lyme \& chronic disease. 1st ed. St. Martin's Press, New York. 2013.

66. Peacock BN, Gherezghiher TB, Hilario JD, et al. New insights into Lyme disease. Redox Biol. 2015; 5: 66-70. http://doi.org/10.1016/ j.redox.2015.03.002

67. Oksi J, Mertsola J, Reunanen M, et al. Subacute multiple-site osteomyelitis cause by Borrelia burgdorferi. Clin Infect Dis. 1994;19: 891-896. doi:10.1093/clinids/19.5.891

68. Oksi J, Kalimo H, Marttila RJ, et al. Inflammatory brain changes in Lyme borreliosis: a report on three patients and review of literature. Brain. 1996; 119: 2143-2154. doi:10.1093/brain/119.6.2143

69. MacDonald AB. Alzheimer's neuroborreliosis with trans-synaptic spread of infection and neurofibrillary tangles derived from intraneuronal spirochetes. Med Hypotheses. 2007; 68: 822-825. doi:10.1016/j.mehy.2006.08.043

70. Miklossy J. Alzheimer's disease-a neurospirochetosis. Analysis of the evidence following Koch's and Hill's criteria. J Neuroinflammation. 2011; 8: 90. http://www.jneuroinflammation.com/content/8/90

71. Preac-Mursic V, Pfister HW, Spiegel H, et al. First isolation of Borrelia burgdorferi from an iris biopsy. J Clin Neuroophthalmology. 1993; 13: 155-161. http://journals.lww.com/jneuro-ophthalmology/Abstract/ 1993/09000/

72. Frey M, Jaulhac B, Piemont Y, et al. Detection of Borrelia burgdorferi DNA in muscle of patients with chronic myalgia related to Lyme disease. Am J Med. 1998; 104: 591-594. doi:10.1016/S0002-9343(98)00112-0

73. Häupl T, Hahn G, Rittig M, et al. Persistence of Borrelia burgdorferi in ligamentous tissue from a patient with chronic Lyme borreliosis. Arthritis Rheum. 1993; 36: 1621-1626. doi:10.1002/(ISSN)1529-0131

74. Müller KE. Damage of collagen and elastic fibres by Borrelia burgdorferiknown and new clinical histopathogical aspects. Open Neurol J. 2012; 6 (Suppl 1): 179-186. doi:10.2174/1874205X01206010179

75. Ramesh G, Borda JT, Dufour J, et al. Interaction of the Lyme disease spirochete Borrelia burgdorferi with brain parenchyma elicits inflammatory mediators from glial cells as well as glial and neuronal apoptosis. Am J Pathol. 2008; 173: 1415-1427. doi:10.2353/ajpath.2008.080483

76. Ramesh G, Santana-Gould L, Inglis FM, et al. The Lyme disease spirochete Borrelia burgdorferi induces inflammation and apoptosis in cells from dorsal root ganglia. J Neuroinflammation. 2013; 10: 88 . http://www.jneuroinflammation.com/content/10/1/88

77. Klempner MS, Noring R, Rogers RA. Invasion of human skin fibroblasts by the Lyme disease spirochete, Borrelia burgdorferi. J Infect Dis. 1993; 167: 1074-1081. doi:10.1093/infdis/167.5.1074

78. Liegner K, Duray P, Agricola M, et al. Lyme disease and the clinical spectrum of antibiotic responsive chronic meningoencephalomyelitides. J Spir Tick-borne Dis. 1997; 4: 61-73.

79. Phillips SE, Mattman LH, Hulínská D, et al. A proposal for the reliable culture of Borrelia burgdorferi from patients with chronic Lyme disease, even from those previously aggressively treated. Infection. 1998; 26: 364-367. http://www.angelfire.com/biz/romarkaraoke/Infect.html

80. Miklossy J, Kasas S, Zurn AD, et al. Persisting atypical and cystic forms of Borrelia burgdorferi and local inflammation in Lyme neuroborreliosis. J. Neuroinflammation. 2008; 5: 40. doi:10.1186/1742-2094-5-40

81. Hodzic E, Imai D, Feng S. Resurgence of persisting non-cultivable Borrelia burgdorferi following antibiotic treatment in mice. PLoS ONE. 2014; 9: e86907. doi:10.1371/journal.pone.0086907

82. Stricker RB, Johnson L. Persistent Borrelia burgdorferi infection after treatment with antibiotics and anti-tumor necrosis factor- $\alpha$. J Infect Dis. 2008; 197: 1352-1353. http://jid.oxfordjournals.org/content/ 197/9/1352.full

83. Magni R, Espina BH, Shah $\mathrm{K}$, et al. Application of Nanotrap technology for high sensitivity measurement of urinary outer surface protein A carboxyl-terminus domain in early stage Lyme borreliosis. J Transl Med. 2015; 13: 346. doi: 10.1186/s12967-015-0701-z

84. Embers ME, Barthold SW, Borda JT, et al. Persistence of Borrelia burgdorferi in rhesus macaques following antibiotic treatment of disseminated infection. PLoS ONE. 2012; 7: e29914. doi:10.1371/journal.pone.0029914

85. Middelveen MJ, Burke J, Sapi E, et al. Culture and identification of Borrelia spirochetes in human vaginal and seminal secretions. F1000Research. 2015; 3: 309. doi:10.12688/f1000research.5778.3
86. Stricker RB, Middelveen MJ. Sexual transmission of Lyme disease: challenging the tickborne disease paradigm. Expert Rev Anti-Infect Ther. 2015; 13: 1303-1306 doi:10.1586/14787210.2015.1081056 